the reader's irritation with the book, which, in spite of its too obvious faults, has many excellent qualities, by leaving the pages uncut and untrimmed-surely an unreasonable offence in a book of this character.

\section{A NEW COPPER-REFINING INDUSTRY IN GREAT BRITAIN.}

$\mathrm{N}$ the last year of the eighteenth century Great 1 Britain produced about 75 per cent. of the world's output of copper. The Cornish miners supplied most of the ore, and the Swansea smelters extracted and refined the metal. In the United States of America only a few tons were made. In I9I3 the positions were reversed. Great Britain smelted and refined barely 6 per cent. of the world's production of this metal, and all but an insignificant fraction was derived from imported ores, matte, blister copper, and precipitate or cement copper. In the same year the United States of America furnished more than 55 per cent, of the world's total, and by far the greater part of this was obtained from home supplies of ore.

Whether in peace or war, copper is, and has long been, second in importance only to iron, not only in the various types of the commercial metal, but also in its numerous alloys. The enormously greater extent to which it is now used is not, however, generally realised. In 1800 the world's production did not exceed ro, ooo tons, and that was probably the high-water mark of the annual production up to that time; in Igoo it had risen to about 500,00o tons, and in I9I2 to about I, ooo, ooo tons. Thus, in little more than a hundred years, the production had increased a hundredfold.

During the war the whole question of the future of the copper-smelting and refining industries of this country was examined and considered by the Non-Ferrous Metal Trades Committee of the Board of Trade under the chairmanship of Sir Gerard Muntz. In due course the Committee reported, but the report has not been published. The announcement is now made in a recent issue of the Times that a syndicate has been formed to set up a large copper refinery in Devonshire, and has chosen a site near Newton Abbot, and that it is proposed to spend nearly 10,000,00ol. on the scheme. The chairman of the syndicate is Sir Gerard Muntz. It is stated that Mr. H. J. Wilson, who originated the scheme, at first intended to harness and utilise the water-power of the Dartmoor plateau, but so much opposition was shown in some quarters that this proposal has been abandoned, at any rate for the time being. It has been decided to utilise a large deposit of lignite, of which it is estimated that more than $800,000,000$ tons are available for the generation of the electric power required. At the site chosen there are tide-water facilities. By-products will be collected and marketed. The power generated will be mainly devoted to the electrolytic refining of copper, but it is considered that it will be so cheap as to enable current to be supplied in bulk to all the towns in South Devon, as well as NO. 2625 , VOL. IO4] to the industries which may be attracted to the neighbourhood.

The lignite deposits have only been used locally to a small extent. The Times states that a few months before the outbreak of war a party of Germans conducted a series of experiments and acquired a considerable tract with the evident intention of developing it on a large scale.

In the years immediately preceding the war the United States of America refined electrolytically more than 90 per cent. of the world's output of crude copper. Most of this production was absorbed by the electrical industry. Great Britain, accordingly, was obliged to obtain the bulk of this type of copper from America, and in 1913 imported about 100,000 tons. In view of the great importance of the home electrical industry, it will be obvious that the proposal to establish a large electrolytic refinery in a suitable locality possesses value which it is not easy to exaggerate. It should be pointed out, however, that the refinery will have to depend mainly upon imported blister copper for its raw material, since only a small amount of this metal is smelted in Great Britain at the present time. There are no longer any considerable home deposits of copper ore, and the few smelters who do exist have found it more and more difficult to obtain smelting materials. The United States of America, by virtue of the extent of its control of its own deposits and of those in Chile, is able largely to influence the price of copper, and the policy pursued by the works there is to attract smelting materials from other countries for treatment. The Americans can afford to pay high prices for imported ores, because the remainder of this raw material is produced at home at a price which is so low that a low average selling price for the whole serves to secure an adequate profit. In Great Britain only a few copper manufacturing firms and one or two companies owning mines abroad can afford to operate smelting works under these conditions. This consideration has no doubt been given its due weight by the syndicate, but it has not been made clear upon what sources they will rely for their blister copper.

In conclusion it must be stated that in this country a small amount of electrolytic refining is carried on, and that there are a large number of manufacturers who are engaged in the furnace-refiring of blister, Bessemer, and other varieties of the crude metallic copper, and in producing the "tough " and "best selected " brands of the metal. The "tough" quality is used chiefly by the engineering and shipbuilding industries, and the "best selected" for the manufacture of alloys. In the production of this class of material the works in Great Britain are, and have long been, pre-eminent. If, therefore, the plans of the syndicate are successful in providing British manufacturers with sufficient supplies of electrolytically refined metal for their purpose, the production of this commodity in Great Britain will be placed on a much more satisfactory footing than it has been for many years.

H. C. H. Carpenter. 